\title{
New Zealand
}

The Annual Report of the New Zealand Red Cross Society for 1960-1961 ${ }^{1}$ opens with the question which Henry Dunant asked in his book "A Memory of Solferino": "Would it not be possible to form, in all countries of Europe, relief societies for the purpose of having care given by volunteers to the wounded in wartime, without distinction of nationality?" The mind thus follows the road which has been travelled for the last hundred years and the report is, amongst many other things, a definite illustration of humanitarian progress.

In his message, the President of the Society recalls that, in addition to the financial aid and gifts of clothing, milk and medical supplies sent overseas, the Red Cross was able, in conjunction with the Government, to send a physiotherapist to Morocco and two doctors to the Congo. Throughout New Zealand, local authorities are planning for Civil Defence and all Red Cross centres should be taking an active part in these arrangements ; in fact, the National Society is one of the two organisations responsible for giving instruction in first aid and home nursing to the general public. The President also recalls that the theme for World Red Cross Day 1961 was " The Red Cross helps across the street, across the nation, across the world " and he ends by saying: "We will continue to endorse this theme."

The Annual Report begins with international activities. "The past twelve months may well be unprecedented in the peacetime history of the New Zealand Red Cross for at no other time has our organisation been so extensively involved in the relief of suffering in other countries. Almost every month has seen the launching of a new appeal for aid.

In April, there was the earthquake in Iran which caused the death of hundreds of people and left numerous injured in its wake. In May, Chile was struck by an earthquake which devastated the southern part of the country. The Red Cross launched a national appeal, as a result of which more than 50 tons of relief supplies

1 Annual Report 1960-61, New Zealand Red Cross Society Incorporated. 
comprising 197 cases of clothing and blankets valued at approximately $£ 15,500$, were sent to the scene of the disaster. The New Zealand Government contributed $£ 10,000$ to this action and the the Red Cross set aside $£_{5} 500$ from its disaster relief fund. In all, more than $f 41,000$ were received by the Society for its action on behalf of Chile. Amongst these gifts, one stands out by virtue of its originality and which, so we are told, was greatly appreciated ; this was a consignment of 1,200 carcasses of frozen mutton which a New Zealand firm had in store in Peru at the time and which it sent to the scene of the disaster. As can be seen from the report, the New Zealand Red Cross responded to numerous appeals for aid to disaster victims in several countries.

With regard to the Society's activities in New Zealand, particular mention should be made of those undertaken on behalf of old people. A section of the report, entitled " Meals on wheels", deals with an interesting development : meals are prepared and delivered to the homes of people too old to move about. During 1960, in the North Canterbury centre alone, 26,200 meals were served, whilst 10 years ago, the figure was 4,600. "Old people's gatherings" are also continuing successfully. They provide the opportunity of meetings in a sympathetic atmosphere and they allow the organisers to keep an eye on members' health. Outings are also organised, on which members of the Junior Red Cross are enthusiastic helpers. It should also be mentioned that, in a club recently set up, a therapist teaches handcrafts to the disabled and this idea has spread to other centres which are applying it to old people as well.

The Red Cross was also present in the hospitals where its members frequently brought comfort to patients who had no friends or relatives. In Wellington, Red Cross members entertained a number of mental patients and organised outings for them. Also in the hospitals, Red Cross volunteers manage cafeterias for out-patients who can thus have snacks free, or at a nominal charge. Sick children are also the subject of Red Cross attention and members contrive to keep them amused by reading to them. The mobile library services and occupational therapy also fall within the province of the Red Cross and the Juniors are very active in these fields.

With regard to Civil Defence, mentioned by the President of the Society in his message, the report points out that the slow but 
steady development of this organisation in New Zealand is proving to be a stimulus for many Red Cross centres. An ever-increasing number of local authorities are laying plans for use in a future emergency and many sections of the Society will be called upon to undertake a variety of first aid tasks.

We should like to end this article on a somewhat original note, but one which expresses only too well the financial worries of a Red Cross Society and the ingenuity which has to be used to overcome them. Having a considerable job of work to do, and consequently having to find a large sum of money, one of the sub-centres compiled a cookery-book with excellent recipes contributed by members and friends of the Red Cross. Two thousand copies were printed and Centres throughout New Zealand were asked to assist with sales. It is with this example of ingenuity and solidarity that we end these notes which, although far too brief, will give readers some idea of the pioneer work being undertaken in New Zealand under the Red Cross emblem.

\section{Norway}

In its issue of July 1960, the Revue internationale published a short article on the results of the co-operation, in Norway, between the Government and the Red Cross with a view to the wide scale dissemination of the Geneva Conventions. This co-operation had made it possible to distribute to the civil and military authorities a complete edition of the text of the four Conventions, printed thanks to the National Society and to the army medical services. Another edition-with commentaries-was also published by a magistrate, whilst the Red Cross itself distributed a résumé of the four Conventions to the military academies and the civil defence training centres, etc. ; moreover, in September 1959, the Red Cross distributed to the crews of all Norwegian vessels, a booklet on the Second Convention, which concerns the condition of wounded, sick and shipwrecked members of armed forces at sea. 